\title{
DWORKIN VERSUS CAPPELLETTI: QUAL O MODELO DE JUIZ ADEQUADO AO ESTADO DEMOCRÁTICO DE DIREITO?
}

\author{
Fernando Hoffmam ${ }^{1}$ \\ Larissa Nunes Cavalheiro ${ }^{2}$ \\ Valéria Ribas do Nascimento ${ }^{3}$
}

\section{RESUMO}

Com a chegada do Estado Social e a necessidade da implementação de vários direitos antes negligenciados pelo Estado, o judiciário vê-se desafiado a participar de tal processo de implementação da chamada questão social. No entanto, quando se adentra o paradigma Estado Democrático de Direito, esta situação desafiadora aumenta em complexidade e, em quantidade. Desta forma, exige-se um novo perfil de jurisdição e de magistrado. Assim sendo, partindo-se da relação entre os modelos cappellettiano e dworkiniano, buscarse-á chegar a um novo modelo de jurisdição e, sobremodo, de juiz. Jurisdição esta, que deve estar blindada contra todo o tipo de decisionismos e arbitrariedades judiciais. Diante disso, o juiz, embora tenha discricionariedade não no sentido forte -, deve ser responsável social e constitucionalmente e, capaz de concretizar e garantir os direitos oriundos do novo paradigma jurídicoestatal, bem como do novo constitucionalismo que o forjou.

Palavras-chave: Juiz. Decisão. Discricionariedade. Integridade. Hermenêutica.

\section{INTRODUÇÃO}

Vislumbra-se no caminhar da modernidade, ao perpassar-se o Estado Liberal, a explosão da questão social e, com isso, o acontecimento do Estado Social de Direito. Tal "acontecimento" traz a reboque a possibilidade de jurisdicionalmente buscar a garantia da efetividade dos direitos sociais, que foram conquistados pela classe proletária - sobremodo - no âmago do modelo estatal social.

Assim, num primeiro momento, será trabalhado de forma a obter uma maior compreensão a respeito do modelo de juiz cappellettiano. Desta forma, buscar-se-á clarificar a concepção de modelo jurisdicional e, ademais, de magistrado, entendida por Cappelletti, bem como, descortinar o papel da discricionariedade para este modelo de juiz, que deverá de forma criativa perseguir a garantia e concretização dos direitos sociais.

No seguimento do trabalho, será analisado o modelo dworkiniano de magistrado, bem como, a sua teoria do direito como integridade. Desta forma, buscar-se-á compreender mais especificamente o contraponto feito por Dworkin às teorias positivistas - sobremodo a hartiana -, bem como, trazer a lume a concepção dworkiniana do direito como integridade, teoria esta, 
contrária às possibilidades discricionárias - em sentido forte - de interpretação do direito, que acreditam ser possível mais de uma resposta correta.

Deste modo, a partir do "confronto" entre os dois modelos de intérprete, mostra-se a necessidade de forjar-se o modelo de magistrado adequado ao Estado Democrático de Direito. Nesse talante, não apenas um novo magistrado é necessário, como também, uma nova jurisdição e, uma nova forma de interpretar/compreender o direito, para que seja possível a blindagem contra arbitrariedades e decisionismos judiciais. Cabe assim, aprofundar-se no tema buscando na hermenêutica - tanto em Heidegger quanto em Gadamer - uma possibilidade de um novo paradigma interpretativo-decisional.

\section{MODELO CAPPELLETTIANO DE JUIZ: DISCRICIONARIEDADE SIGNIFICA DECISIONISMO?}

Inicialmente, cabe trazer a baila algumas considerações sobre a eclosão do Estado Social como possibilidade de "ruptura" com o modelo estatal Liberal e, que, a partir de si - Estado Social - estabelece uma nova preocupação, qual seja, a implementação da questão social. Neste ponto do percurso, nasce uma obrigação do Estado em participar da vida dos sujeitos jurídico-sociais possibilitando a estes, que atinjam uma condição de viver dignamente, sendo atendidos alguns direitos que tinham sido esquecidos pelos então revolucionários.

Assim, ganha contornos mais abertos a atividade jurisdicional, que deve participar ativamente da persecução deste novo estado de coisas oriundas das lutas proletárias. Por óbvio, abandona-se assim, a concepção estritamente normativo-positivista da jurisdição liberal - meramente declaratória da vontade da lei, do soberano - e passa-se a uma jurisdição que persegue os anseios do tecido vivo da sociedade.

Desta forma, nasce uma jurisdição - e por evidente um juiz - criativa, que tem a força de, em interpretando o direito posto, criar respostas que possibilitem a concretização dos ideais sociais do Estado. Por assim dizer, o juiz é alçado à condição de ativo participante da vida sociopolítica, devendo solucionar conflitos de outra espécie - que não mais apenas os abarcados pelo liberalismo - quais sejam, os conflitos sociais.

Este novo juiz, erigido do modelo estatal social é sim um criador do direito, no entanto, como bem alerta Cappelletti, não é um criador totalmente livre de amarras. Tal modelo de magistrado, por tornar-se intérprete passa a ter discricionariedade - ou o movimento inverso, por passar a ter discricionariedade, torna-se intérprete -, a discricionariedade necessária para livrá-lo das justas amarras do positivismo-normativista ${ }^{4}$.

Neste caminho, o juiz torna-se verdadeiro intérprete do Direito, cabendoIhe a missão de, ao interpretar os textos legislativos, ou suprir as lacunas deixadas pelo mesmo - texto - tornar possível a questão social. Deste modo, discricionariamente 0 juiz ora declarador de vontades, torna-se um juiz 
construtor do arcabouço político-social, que só vai ser totalmente construído a partir da atividade jurisdicional marcadamente intensa nestes novos tempos. Para tanto, cabe ressaltar que:

Discricionariedade não quer dizer necessariamente arbitrariedade, e o juiz, inevitavelmente criador do direito, não é necessariamente um criador completamente livre de vínculos. Na verdade, todo o sistema jurídico civilizado procurou estabelecer e aplicar certos limites à liberdade judicial, tanto processuais quanto substanciais ${ }^{5}$.

Por tais motivos, o juiz passa de uma condição de inércia, a uma condição de participante interventivo e ativista, mas não arbitrário capaz de solidificar as bases que originarão o Estado Democrático de Direito - donde os direitos sociais já estão - no caso brasileiro deveriam estar - concretizados $^{6}$. Neste ínterim, o Estado passa a intervir - assumindo os riscos advindos dessa maior intervenção - em todos os domínios da vida, seja econômico, cultural, social, podendo assim, se fazer presente na vida dos indivíduos, os quais tinha relegado ao esquecimento, pelo menos no que tange as questões sociais ${ }^{7}$.

Neste trilhar, não cabe mais aos novos tempos o juiz irresponsável do ancien regime, que se encontrava imobilizado pelos grilhões do direito posto. Este magistrado, por estar ocultado sob o manto da norma posta não tinha responsabilidade alguma quanto ao nexo entre a sua decisão e a repercussão social da mesma, pois não era ele que decidia ${ }^{8}$. Porquanto, ao surgir um juiz que efetivamente (re)cria o direito, este sim, está comprometido decisoriamente com os efeitos provocados no âmbito social. Ademais, foi ele quem criativamente decidiu - deu uma "resposta" - assentada na nova concepção jurídico-estatal proveniente da guinada social ${ }^{9}$.

Assim, o juiz cappellettiano mesmo criativamente, trabalha adstrito aos ditames do paradigma estatal social, ou seja, consternado no momento da criação, criar um direito intrinsecamente social. Neste passo, embora não esteja aferrado à norma posta, está sim, atrelado a parâmetros sociais de construção de uma vida digna, ensejadores de um "estado de felicidade" devidamente alcançado pelos sujeitos jurídico-sociais. Com efeito:

\footnotetext{
Na proteção de tais direitos, o papel do juiz não pode, absolutamente, limitar-se a decidir de uma maneira estática o que é agora legítimo ou ilegítimo, justo ou injusto; ao contrário, constitui frequente responsabilidade do juiz decidir se determinada atividade estatal, mesmo quando largamente discricional - ou a inércia, ou em geral dado comportamento dos órgãos públicos -, está alinhado com os programas prescritos, frequentemente de maneira um tanto vaga, pela legislação social e pelos direitos sociais ${ }^{10}$.
}

Desta forma, resta claro que mesmo o juiz "criativo" cappellettiano não é totalmente livre para criar. Ele deve criar nos caminhos delineados pelo Estado social e, pelos direitos sociais consagrados no bojo desta modalidade estatal. Ele deve criar, para que estas verdadeiras conquistas sociais sejam implementadas e garantidas aos cidadãos, para que seja implementado no seu 
todo sociológico um verdadeiro Estado Social de Direito - ou Estado de Direitos Sociais ${ }^{11}$.

Neste jaez, o juiz, intérprete criativo da lei - seja no que tange à esfera privada quanto pública - é uma imposição e porque não dizer, uma realidade destes novos tempos. Sendo clara a antítese quanto aos modelos de juiz - e de jurisdição - da modernidade, devendo, romper com os paradigmas oitocentistas e dar lugar a uma jurisdicionalidade invasora, interventiva e ativamente executora da questão social ${ }^{12}$.

Neste momento histórico o qual se encontra lançado o direito, o percurso feito na mudança do que é a atividade jurisdicional, enquanto função do juiz, não pode ser retornado. Não cabe mais agora, discutir-se ter ou não ter discricionariedade o juiz, ele a tem. Discricionariedade esta, que como bem lembra Ovídio Baptista é a necessária para decidir-se antes de decidir, é a que faz do direito uma ciência hermenêutica e, por excelência, interpretativocompreensiva $^{13}$.

Nesta maré, adentra-se o paradigma instituído pelo Estado Democrático de Direito já com uma nova concepção acerca do que seria - é - atribuição do juiz. No entanto, devido às profundas mudanças introduzidas por este novo modelo estatal, a complexidade do problema a respeito da discricionariedade judicial toma novas proporções. Face ao novo paradigma, não se pode retornar a discussão de, se o juiz tem ou não discricionariedade ao interpretar, mas sim, deve discutir-se o quanto de discricionariedade deve ser - é - permitido ao magistrado. No seio do novo paradigma, discricionariedade, jamais poderá gerar qualquer tipo de arbitrariedade judicial, pois, a criação do direito por parte do juiz não se dá a partir de um grau zero de significado, mas sim, a partir do que está positivado e delimitado principiologicamente pela Constituição.

O juiz neste tempo histórico esta condenado a interpretar e, quando se interpreta se (re) cria. Logo ao interpretar o Direito - a norma constitucionalmente está o intérprete a criar, no entanto, criará adstrito às práticas jurídico-interpretativas principiológicas ${ }^{14}$. Nesta quadra da história "não há como vedar a criação 'constitucional' e, portanto, 'responsável' do Direito pelo juiz" ${ }^{15}$, pois será desta forma que o juiz-intérprete será jogado dentro da textura social complexa da contemporaneidade.

Logo, fica evidente que ocorreram modificações nas práticas jurídicopolíticas da modernidade até este momento. Tais modificações, assim como conduziram o direito a novas possibilidades de consolidação, conduziram-no também, a zonas de turbulência. Para tal, com a retomada do direito enquanto atividade interpretativa surge novas teorias quanto à interpretação e aplicação do mesmo - Direito. Uma delas é que se passa a tratar a seguir.

\section{JUIZ HÉRCULES DWORKINIANO E A INTEGRIDADE ENQUANTO PARÂMETRO DECISIONAL}

Neste passo, em se tratando de teorias da decisão jurídica, opta-se pela 
teoria dworkiniana. Dworkin centra sua concepção a respeito da decisão jurídica nas críticas que faz ao positivismo, sobremodo, ao de feição hartiana. Hart defende a posição de que, em não havendo um padrão normativo específico capaz de guiar o juiz na persecução da decisão - da resposta ao caso concreto - estará o juiz, liberto para utilizar todo e qualquer padrão, que considerar ideal para alcançar a decisão válida. Deste modo, Hart permite ao magistrado - intérprete - um poder discricionário desmensurado, que 0 possibilita criar livremente a resposta adequada ao caso ${ }^{16}$.

Esta posição hartiana, vem assentada na concepção do direito enquanto um sistema fechado de regras ${ }^{17} \mathrm{e}$, parte do pressuposto, de que a linguagem jurídica é por excelência vaga de sentido. Neste caso, para se chegar às respostas corretas, quando tratamos de casos difíceis, em que são possíveis mais de uma resposta, cabe ao magistrado escolher discricionariamente entre as respostas disponíveis, ou, "mais" discricionariamente ainda, criar uma resposta com base na sua consciência ${ }^{18}$. Em Dworkin, é a esta concepção positivista de Direito enquanto sistema de regras e, à pretensa vagueza de sentido dos textos jurídicos, que está ligada a discricionariedade. Para o autor, o Direito enquanto sistema de regras não consegue perceber a possibilidade de fechamento trazida pela construção principiológica do direito ${ }^{19}$.

Assim, Dworkin rejeita a possibilidade do magistrado, ao decidir, ter tamanha discricionariedade. Desta forma, o autor faz uma classificação a respeito do poder discricionário, atribuindo à discricionariedade três sentidos diferentes. No primeiro sentido, ele compreende discricionariedade quando um homem tem seu dever definido por padrões que pessoas razoáveis podem interpretar de maneira diferente; no segundo sentido, Dworkin compreende poder discricionário "se sua decisão for definitiva", com o condão de nenhuma outra autoridade poder revê-la ou desconsiderá-la; no terceiro sentido, o autor compreende o poder discricionário na situação em que há um conjunto de padrões, que apesar de lhe impor deveres, não visa impor o dever de tomar uma decisão específica ${ }^{20}$.

Nesta senda, a partir da classificação dworkiana para discricionariedade, é no terceiro sentido - sentido forte - apresentado pelo autor que o magistrado jamais deverá ser discricionário - ter discricionariedade. Pois, este poder discricionário tido por Dworkin, como a terceira manifestação de discricionariedade jurisdicional é que permite ao magistrado arbitrariamente inventar uma decisão/resposta - constitucional ou não, na contemporaneidade brasileira - para o caso concreto, com base nas suas "íntimas convicções". Provoca assim, práticas jurídico-interpretativas ativistas e decisionistas, que dão ao intérprete o poder de assujeitar o texto, gerando decisões arbitrárias e, adentrando-se desta forma às zonas de escuridão do subjetivismo ${ }^{21}$.

Como opção às possibilidades discricionárias positivistas hartianas, Dworkin apresenta a concepção de direito como integridade. Neste diapasão a prática interpretacional do Direito na pós-modernidade deve estar pautada em padrões de integridade que exprimam uma construção coerente de justiça e equidade, onde as formulações jurídicas serão verídicas se ordenadas por 
princípios de justiça, equidade e devido processo legal ${ }^{22}$.

Para Dworkin, a resposta em não estando na construção normativa, deve o juiz buscá-la na construção principiológica do direito, já que, não apenas de padrões normativos - regras - é constituído o sistema jurídico, mas também, de princípios que, devem nortear o magistrado na busca pela resposta correta - em se tratando do novo paradigma, da resposta constitucionalmente correta ${ }^{23}$. O juiz assim, ao operar o direito, maneja um direito com história - feito na história, na tradição - compromissado com padrões ético-morais fecundados no âmago da sociedade e, oriundos de determinada ordem político-jurídica ${ }^{24}$.

Assim, fica claro, que para o autor o direito não pode mais ser visto meramente como um sistema fechado de regras. Porquanto, direitos nestes dias é um sistema aberto - que fique claro, não tem o sentido de "abertura" a múltiplas respostas - de regras e princípios. Deve-se levar em conta a textura principiológica do direito ao decidir-se, a necessidade e a tradição da comunidade, bem como, a tradição decisória assentada como padrão norteador de decisões futuras - embora não vinculando a decisão futura à decisão anterior ${ }^{25}$. Com efeito:

Nesse sentido, a preciosa lição de Dworkin (Law's Empire), ao lembrar que quando mais de uma solução se apresentar a partir dessa "conduta interpretativa", o juiz deverá optar pela interpretação que, do ponto de vista da moral política, melhor reflita a estrutura das instituições e decisões da comunidade, ou seja, a que melhor represente o direito histórico e o direito vigente, sendo que esta seria, assim, a resposta correta para o caso concreto ${ }^{26}$.

Deste modo, a decisão só poderá ser construída integrativa e coerentemente dentro de um contexto. Sendo vista como a continuidade de uma prática social, jurídica e política, refletida nela mesma - decisão enquanto resposta adequada a determinado caso. Assim, rejeitam-se tanto as universalizações de respostas, quanto o perigo do casuísmo, o que poderia sugerir que o juiz só deve levar em conta o caso e mais nada - como se o caso concreto não estivesse no mundo ${ }^{27}$.

Neste caminho, o intérprete sempre estará envolto em algo maior, em algo que existe desde-já-sempre funcionando como um vínculo entre ele intérprete - e o mundo prático. Magistrado, caso concreto, direito e, todas as variantes operadas na busca pela resposta fazem parte de um mundo circundante que participa sempre da formação do sentido pretendido pela singularidade do caso - veja-se nesse ponto a importância da hermenêutica, 0 que será aprofundado adiante.

Sendo mais claro, toda decisão deve se fundar em um compromisso (pré-compreendido). Esse compromisso passa pela reconstrução da história institucional do direito - aqui estamos falando, principalmente, dos princípios enquanto indícios formais dessa reconstrução - e pelo momento de colocação do caso julgado dentro da cadeia da integridade do direito. Não há decisão que parta de um "grau zero de sentido" ${ }^{28}$. 
Por óbvio, será sempre o intérprete a fazer a mediação de sentido entre texto e norma, e a dar resposta ao caso concreto a partir da mediação feita. Para tanto, Dworkin cria a figura de Hércules, um juiz com capacidade sobrehumana a quem caberá construir integrativamente a resposta correta. Assim, Hércules caminhará ao encontro da resposta correta. Porém, esta referida capacidade "sobre-humana" de Hércules jamais pode ser confundida com a possibilidade de solipsisticamente tal juiz ser um detentor pleno de significado(s), que não o oriundo do texto constitucional ${ }^{29}$. Com efeito:

\begin{abstract}
Para Hércules, o direito real contemporâneo consiste nos princípios que proporcionam a melhor justificativa disponível para as doutrinas e dispositivos do direito como um todo. Ele se guia pelo princípio da integridade na prestação jurisdicional, que o força a ver, na medida do possível, o direito como um todo coerente e estruturado. Hércules deve descobrir a série coerente de princípios capaz de justificar a história institucional de um determinado sistema de direitos, do modo como é exigido pela eqüidade e deve ampliar sua teoria de modo a incluir a idéia de que uma justificação da história institucional pode apresentar uma parte dessa história como um erro ${ }^{30}$.
\end{abstract}

Assim, o modelo de juiz herculeano é uma metáfora criada por Dworkin, para mostrar que é possível encontrar-se uma resposta, a partir de padrões de integridade e coerência. Por evidente, a quem incumbe esta busca pela resposta correta - constitucional e principiologicamente - é o juiz, no entanto, não mais o juiz solipsista da modernidade que assujeitava o texto, mas sim, o juiz que trabalha texto e norma na sua intersubjetividade significativa ${ }^{31}$.

Desta forma na visão integralista do direito não há espaço para o poder discricionário defendido por Hart - a terceira forma de discricionariedade jurídica descrita por Dworkin - já que dworkianamente a decisão dar-se-á com base em padrões jurídico-interpretativos construídos sob o signo da textura principiológica do Direito ${ }^{32}$. Assim, o juiz/intérprete deverá identificar direitos e deveres legais - no direito positivado infraconstitucional - até onde for possível e, em não havendo mais possibilidade de se constatar tais padrões legais, deverá o magistrado construir responsavelmente a interpretação adequada as formulações morais e políticas da comunidade, bem como, a sua "tradição" decisória $^{33}$.

No entanto, no que tange ao Brasil, ainda encontra-se o direito - e, sobremodo a decisão jurídica - envolto em subjetividades interpretativas oriundas da má compreensão do novo paradigma pelo magistrado. Deste modo, cabe agora (re) compreender a função do intérprete em terrae brasilis, bem como, desvelar a função jurisdicional em sua forma responsável e constitucionalmente comprometida.

\title{
4 O MAGISTRADO DO/NO ESTADO DEMOCRÁTICO DE DIREITO: PELA RESPONSABILIDADE CONSTITUCIONAL NO MOMENTO DE DECIDIR
}


De pronto, a situação brasileira é um tanto peculiar, ademais, passou-se pelas modificações surgidas da evolução paradigmático-estatal de forma incompleta, tendo o Estado Social não passado de um simulacro que deixounos promessas incumpridas e direitos não concretizados. Nesse sentido, caberá ao intérprete neste momento garantir e concretizar direitos de maneira responsável, estando adstrito ao texto constitucional.

Assim, mesmo com a vigência da Carta Constitucional brasileira de 1988 a mais de 20 anos, segue a mesma, sem eficácia completa, sobremodo, no que tange aos direitos e garantias fundamentais. Nota-se, que em meio ao Estado Democrático de Direito, ainda hoje em terrae brasilis, não são vistos concretizados por parte da ordem político-administrativa, direitos básicos do cidadão, tais como, saúde, moradia, educação, saneamento básico, entre outros.

Nesta trilha, em meio ao paradigma estatal pós-moderno, onde caberia ao Estado concretizar as promessas esquecidas da modernidade, em o mesmo - Estado - falhando, volta-se para o judiciário o eixo de tensão social. Neste panorama, seria o juiz quem deveria no caminho delineado pela Constituição preencher as lacunas deixadas pelo legislador na persecução do todo valorativo principiológico-constitucional, apontado pelo novo paradigma ${ }^{34}$. Com feito:

\begin{abstract}
Como o direito é um saber prático que deve servir para resolver problemas e concretizar as promessas da modernidade que ganharam espaço nos textos constitucionais, a superação dos obstáculos que impedem o acontecer do constitucionalismo de caráter transformador, estabelecido pelo novo paradigma do Estado Democrático de Direito, pressupõe a construção das bases que possibilitam a compreensão do estado da arte do modus operacional do direito, levando em conta um texto constitucional de nítida feição compromissória e dirigente, e que, passadas quase duas décadas, longe esta de ser concretizado[.... $]^{35}$.
\end{abstract}

Logo, em meio a este novo discurso jurídico-constitucional, as lacunas interpretativas deixadas durante a modernidade vêm a ser preenchidas pelas novas posturas no modo de interpretar, sobretudo a "hermenêutica-ontológica". Que, deixam de hipostasiar o método e o procedimento, colocando no modo de ser e na faticidade, o locus da compreensão. Assim, salta-se do fundamentar para o compreender, onde este compreender não é mais um agir do sujeito solipsista da modernidade - e, sim, um modo-de-ser - do sujeito, pois este ainda vive, só que, responsavelmente - que se dá em uma intersubjetividade ${ }^{36}$.

Nesta maré, desde já, deixa-se claro que, será a partir da hermenêutica - heideggeriana e gadameriana - enquanto verdadeiro acontecer do ser-nomundo, que se dará o desvelamento do "ser" do direito que por muito esteve está - encoberto pelo manto do positivismo. Este desvelar acontecerá quando a Constituição ganhar o seu sentido - enquanto ser-no-mundo -, pois estando no mundo, ela poderá "constituir", orientando uma nova prática jurídicointerpretativa e, permitindo assim o desvelar da jurisdição, enquanto jurisdição constitucional(izada) e do intérprete enquanto sujeito - ser-em-si - responsável constitucionalmente ${ }^{37}$. 
Deste modo, fica claro o papel ativo que cabe ao juiz na busca pela garantia e concretização dos direitos positivados constitucionalmente Cappelletti. Porquanto, esta "atividade" do juiz dar-se-á no caminho descrito pela Constituição na sua forma principiológico-valorativa e, pautada por padrões consolidados de integridade e coerência - Dworkin. Assim, como já referido, é nítido que o magistrado tem sim um "algo" de discricionariedade, "algo" este, que lhe permite utilizando-se da textura principiológica e da prática jurídico-decisória encontrar a resposta constitucionalmente adequada correta $^{38}$. No entanto:

[...] ninguém está a advogar uma noção ingênua e simplista de que as respostas corretas estejam prontas e disponíveis em uma caixa-forte, ao de verdades metafísicas. A resposta correta, ao contrário, está no esforço de descobrir os direitos relativos às partes, em oposição à idéia de inventá-los. Dworkin fala das "práticas que são parte do nosso processo legal", enquanto Gadamer diz que, quando o juiz pretende adequar as leis às necessidades do presente, tem diante de si uma "tarefa prática" (praktische Wissenschaft). "O que não quer dizer", acrescenta Streck, " que sua interpretação da lei seja uma tradução arbitrária, uma invenção” 39 .

Neste talante, é a partir do modo-de-ser-no-mundo, que se dará o desvelar da jurisdição - enquanto condição de possibilidade na busca pelo(s) sentido(s) dos textos - e, o desvelar do intérprete - enquanto ser-no-mundo. Pois o novo modus interpretativo do Direito busca respostas, enquanto formações de sentido oriundas do compreender, sendo este compreender acontecido a partir de algo - a pré-compreensão - que está no mundo e, por isso, não parte de um vácuo significativo a mercê do sujeito ${ }^{40}$.

Assim, apresenta-se este modus compreensivo circular, como condição de possibilidade para o rompimento com as velhas práticas interpretativas subsuntivo-dedutivas, pois aqui, está o intérprete circundado pelos sentidos e suas possibilidades. O intérprete trabalha jogado no círculo hermenêutico jogado no mundo - enquanto significante e significado. Não está o intérprete solipsisticamente "dando" significados nem, recebendo plenipotenciariamente um significado pré-dado pelo texto, mas sim, enquanto "ser" significando um "algo" para daí sim, dar significado a um outro "algo" a partir do mundo e não, do nada".

Resta claro, que a atividade interpretativa está ligada indissociavelmente a uma atribuição de significados. O que acontece, porém, é que, com a invasão do direito pela filosofia - da linguagem - este atribuir de sentidos ocorre mediado pela linguagem - a relação sujeito-objeto se dá no horizonte lingüístico. Os sentidos pelos quais pugna o direito neste momento histórico, não são sentidos construídos arbitrariamente a fim de possibilitar decisionismos judiciais, mas sim, são sentidos construídos hermeneuticamente, a partir da relação intersubjetiva: intérprete, texto, norma e caso concreto - inseridos em uma cadeia prático-decisória. A linguagem não será mais uma terceira coisa na relação interpretativo-compreensiva, mas sim, é a condição de possibilidade do 
"dar" sentido ao texto - constitucional.

[...] a partir de sua situação hermenêutica, e de um sentido que já vem antecipado pela pré-compreensão, o intérprete produzirá este sentido. É evidente que ele não é livre para dizer o "sentido que melhor the aprouver", o que o lançaria no autoritário mundo da relativização sofística. O sentido necessariamente exsurgirá na conformidade do texto constitucional, entendido no seu todo principiológico, isto é, no seu "sentido ontológico-existencial", e não meramente "ôntico-existencial" ${ }^{42}$.

Neste ínterim, a defasagem conteudística do direito brasileiro em se tratando de direitos e garantias fundamentais, bem como, a não consolidação do programa social proposto pela Constituição de 1988, faz com que o judiciário encontre-se desafiado. Desafiado, a superar o positivismo hartiano sem cair nas falácias da possibilidade de se cindir interpretação, compreensão e aplicação, nem deslizar para o lado das proposições discricionárias na busca por respostas.

Assim, caberá ao intérprete além de decidir fundamentadamente, justificar a sua fundamentação - ou seja, o porquê decidiu desta forma. Quando a resposta a essa pergunta for a de que, assim decidiu porque tal resposta era a guiada pelo texto constitucional, pela prática jurídico-decisória anterior e, ainda, a necessária para a garantia e concretização dos direitos humano-fundamentais, estará "bem feita" a fundamentação e, com isso, a decisão atendeu a melhor resolução do - para o - caso concreto, face às circunstâncias apresentadas ${ }^{43}$. Daí que:

\begin{abstract}
A explicitação da resposta de caso deverá estar sustentada em consistente justificação, contendo a reconstrução do direito, doutrinária e jurisprudencialmente, confrontando tradições, enfim, colocando a lume a fundamentação jurídica que, ao fim e ao cabo, legitimará a decisão no plano do que se entende por responsabilidade política do intérprete no paradigma do Estado Democrático de Direito. A justificativa (a fundamentação da fundamentação, se assim se quiser dizer) é condição de possibilidade da legitimidade da decisão ${ }^{44}$.
\end{abstract}

Desta maneira, mesmo estando o momento interpretativo-compreensivo ancorado na hermenêutica, o intérprete cria. O encontro das tradições do intérprete e do texto interpretado não exprime sempre uma mesma compreensão. Assim, o intérprete enquanto no caminho hermenêuticointerpretacional não reproduz sentido, mas sim, produz um sentido com base no que lhe foi dado pelo mundo. O intérprete a cada busca de sentidos se reinsere no círculo hermenêutico buscando uma nova compreensão sobre o sentido do texto para aquele momento histórico ${ }^{45}$.

Nesse sentido, a tradição trará para o momento interpretativo "a prática jurídica da comunidade" - Dworkin - como "fundamento" para o decidir, para a resposta encontrada - desvelada - hermeneuticamente. Tendo-se por parâmetro uma hermenêutica da integridade, nunca o intérprete decidirá poderá decidir - a partir de um "grau zero" significativo, devendo estar sempre 
atrelado às concepções morais, éticas, políticas e jurídicas, bem como, a história efeitual de certa sociedade em determinada época.

Assim, resta cristalino, que o modelo de magistrado necessário ao Estado Democrático de Direito, é o de um magistrado ativo/criativo Cappelletti - na busca pela substancialidade constitucional. No entanto, esta criação do direito dar-se-á a partir da textura aberta principiológica a qual, será fundamento para toda e qualquer decisão -, pois atrás de cada regra há um princípio - comprometido social e constitucionalmente. Bem como, será ainda, a resposta correta dada de maneira a integrar coerentemente a prática jurídica assentada ao longo da história, ou seja, ao longo de uma tradição jurídicodecisória - Dworkin.

E por tal motivo, não restam dúvidas de que o magistrado em terrae brasilis deve ser sim, ativo, mas, sem ser ativista, ter discricionariedade para interpretar hermenêutico-integrativamente o direito, mas, sem ser arbitrário ou decisionista, ser sim, um juiz que (re) cria o direito, mas, não o cria a partir de um grau zero de significado, bem como, ser combativo e participativo, mas, sem extrapolar as suas funções. Ou seja, pede-se um juiz responsável, que cumpra os ditames constitucionais e, trabalhe na persecução de um verdadeiro Estado Democrático de Direito.

\section{CONCLUSÃO}

O positivismo jurídico trata o direito como um sistema fechado de regras, - que, possibilita a exacerbação do poder discricionário por parte do magistrado no momento de decidir e, logo, faz surgir a possibilidade concreta de decisões arbitrárias judicialmente.

No entanto, no decorrer dos tempos tal tese foi se mostrando ineficaz às novas roupagens assumidas pelo contexto social. Com a eclosão do Estado Social e a necessidade de valorar-se ético e moralmente o direito, tal mostrouse como um sistema "falido" e, ultrapassado pelos acontecimentos históricosociais.

Tal crise de modelo jurídico acirrou-se ao adentrar o paradigma instituído pelo Estado Democrático de Direito. Nestes novos tempos, as demandas jurídicas aumentaram não só em quantidade, como em complexidade, sendo necessário ao direito um novo modelo jurisdicional e, ademais, um novo modelo de juiz - intérprete.

Deste modo, a partir da compreensão dos modelos cappelletiano e dworkiniano de magistrado, buscaram-se delinear através de uma simbiose de ambos os modelos, o novo magistrado adequado à modalidade estatal democrática de direito. Magistrado este, que, embora tenha certa discricionariedade - em sentido fraco - não está liberado de maneira alguma, para cometer decisionismos ou arbitraridades judiciais. 
Assim, mostra-se evidente que será através da hermenêutica - não como método, mas como modo-de-ser-no-mundo - que o direito fundará um novo paradigma jurídico-interpretativo. Tal paradigma permitirá ao magistrado fazer uso de sua discricionariedade inserido na circularidade hermenêutica - e por óbvio no mundo - estando assim, circundado pelos elementos interpretativo-compreensivos, podendo de maneira responsável atribuir sentido aos textos, pautado por padrões de coerência e integridade, que lhe possibilite chegar à resposta constitucionalmente adequada - correta - ao caso concreto.

\section{DWORKIN VERSUS CAPPELLETTI: WHAT IS THE ROLE MODEL OF JUDGE ON DEMOCRATIC RULE OF LAW?}

\section{ABSTRACT}

The rise of the Welfare State and the ascension of some rights previously overlooked by the State, the Judiciary as a power is called to be included in this arrangement. However, when it enters the democratic Rule of Law paradigm this situation increases in complexity and in extension. It requires a new role to the jurisdiction of the magistrate. Starting from the relation between cappellettian and dworkinian models, the purpose of this paper is the explanation about this new type of Judge. This actuation must be shielded against any type of decisionism and arbitrariness, although there are some discretionary acts - not in the strong sense. The Judge needs to be socially and constitutionally responsible and capable of achieving and securing the rights from the new paradigm of the State and the new constitutionalism derived from it.

Keywords: Sentence. Discretionary acts. Hermeneutics. Integrity. Judge.

\section{NOTAS:}

1. Especializando em Direito e Novas Tecnologias Informacionais pelo Centro Universitário Franciscano (UNIFRA); Bacharel em Direito pelo Centro Universitário Franciscano (UNIFRA); Membro do Grupo de Pesquisa Teoria Jurídica no Novo Milênio, vinculado à UNIFRA e ao CNPQ. E-mail: ferdhoffa@yahoo.com.br

2. Especialista em Direito Público pela Escola Superior da Magistratura Federal (ESMAFE-RS); Especializanda em Educação Ambiental pela Universidade Federal de Santa Maria (UFSM); Bacharel em Direito pelo Centro Universitário Franciscano. Advogada. Santa Maria - RS. E-mail: laranunes7@hotmail.com

3. Doutora em Direito Público pela Universidade do Vale do Rio dos Sinos (UNISINOS), com período de pesquisa na Universidade de Sevilha; Mestre em Direito Público pela Universidade de Santa Cruz do Sul (UNISC); Graduada em Direito pela Universidade Federal de Santa Maria (UFSM); Professora de Direito Constitucional e Direitos Humanos da Faculdade de Direito de Santa Maria (FADISMA); Professora de Direito Internacional Público e do Programa de Mestrado em Direito da Universidade Regional Integrada do Alto Uruguai e das Missões (URI/Santo Ângelo); Advogada. Email: valribas@terra.com.br

4. CAPPELLETTI, Mauro. Juízes Legisladores?. Porto Alegre: SAFE, 1999, p. 21-22.

5. CAPPELLETTI, Mauro. Juizes Legisladores?. Porto Alegre: SAFE, 1999, p. 23-24. 
6. ISAIA, Cristiano Becker. Processo Civil, Atuação Judicial e Hermenêutica Filosófica: a metáfora do juiz instrutor e a busca por respostas corretas em direito. Faticidade e Oralidade. Curitiba: Juruá, 2010, p. 40.

7. CAPPELLETTI, Mauro. Juízes Legisladores?. Porto Alegre: SAFE, 1999, p. 39.

8. CAPPELLETTI, Mauro. Juízes Irresponsáveis?. Porto Alegre: SAFE, 1989, p. 17-18.

9. CAPPELLETTI, Mauro. Juízes Legisladores?. Porto Alegre: SAFE, 1999, p. 42.

10. CAPPELLETTI, Mauro. Juízes Irresponsáveis?. Porto Alegre: SAFE, 1989, p. 22.

11. CAPPELLETTI, Mauro. Juízes Legisladores?. Porto Alegre: SAFE, 1999, p. 66-67.

12. ISAIA, Cristiano Becker. Processo Civil, Atuação Judicial e Hermenêutica Filosófica: a metáfora do juiz instrutor e a busca por respostas corretas em direito. Faticidade e Oralidade. Curitiba: Juruá, 2010, p. 41.

13. SILVA, Ovídio A. Baptista da. Processo e Ideologia: o paradigma racionalista. Rio de Janeiro: Forense, 2006. Passim.

14. HOMMERDING, Adalberto Narciso. Fundamentos Para Uma Compreensão Hermenêutica do Processo Civil. p. 166.

15. HOMMERDING, Adalberto Narciso. Fundamentos Para Uma Compreensão Hermenêutica do Processo Civil. p. 174.

16. RODRÍGUEZ, Cezar. La Decisión Judicial: el debate Hart-Dworkin. Bogotá: Siglo Del Hombre, 1997, p. 32-33.

17. Cabe aqui, referir que o Direito neste quadrante histórico, deve ser visto como um sistema de regras e princípios, onde a produção, interpretação e aplicação do direito deve se dar também a partir de parâmetros principiológicos do que é o direito neste dado momento histórico. Assim, embora se conceda normatividade aos princípios, não se coaduna aqui com a tese de que princípios são espécies - assim como as regras do gênero norma jurídica e, que, por tal motivo adquirem força normativa. Princípios, não ganham força normativa por serem positivados pelo legislador - seja constitucional seja infraconstitucional -, eles desde-já-sempre tem normavitidade - por estarem inseridos em um contexto ético-valorativo do social -, que apenas é desvelada - a sua força normativa - no momento de sua aplicação. STRECK, Lenio Luiz. Hermenêutica Jurídica $\mathbf{e}(\mathbf{m})$ Crise: uma exploração hermenêutica da construção do Direito. Porto Alegre: Livraria do Advogado, 2005, p. 246. Corroborando: "Por tudo isso, deve-se reconhecer razão à Lenio Streck quando diz que há uma diferença ontológica entre regra e princípio. Isso representa um resgate do mundo prático no âmbito do pensamento jurídico. Nos princípios se manifesta o caráter de transcendentalidade. Em todo caso, compreendido e interpretado já sempre aconteceram os princípios - e não o princípio; toda decisão deve sempre ser justificada na comunidade dos princípios, como nos mostra Dworkin. Não há regras sem princípios, do mesmo modo que não há princípios sem regras. Há entre eles uma diferença, mas seu acontecimento sempre se dá numa unidade que é a antecipação de sentido". OLIVEIRA, Rafael Tomaz de. Decisão Judicial e o Conceito de Princípio: a hermenêutica e a (in)determinação do Direito. Porto Alegre: Livraria do Advogado, 2008, p. 223.

18. RODRÍGUEZ, Cezar. La Decisión Judicial: el debate Hart-Dworkin. Bogotá: Siglo Del Hombre, 1997, p. 34.

19. OLIVEIRA, Rafael Tomaz. Decisão Judicial e o Conceito de Princípio: a hermenêutica e a (in)determinação do Direito. Porto Alegre: Livraria do Advogado, 2008, p. 191.

20. DWORKIN, Ronald. Levando Os Direitos Á Sério. São Paulo: Martins Fontes, 2007, p. 109.

21. OLIVEIRA, Rafael Tomaz. Decisão Judicial e o Conceito de Princípio: a hermenêutica e a (in)determinação do Direito. Porto Alegre: Livraria do Advogado, 2008. Passim.

22. DWORKIN, Ronald. O Império do Direito. São Paulo: Martins Fontes, 2007, p. 271 272.

23. SAAVEDRA, Giovani Agostini. Jurisdição e Democracia: uma análise a partir das teorias de Jürgen Habermas, Robert Alexy, Ronald Dworkin e Niklas Luhmann. Porto Alegre: Livraria do Advogado, 2006, p. 70.

24. RAMIRES, Maurício. Crítica À Aplicação de Precedentes No Direito Brasileiro. Porto Alegre: Livraria do Advogado, 2010, p. 94. 
25. DWORKIN, Ronald. O Império do Direito. São Paulo: Martins Fontes, 2007, p. 172 , 202-203.

26. STRECK, Lenio Luiz. Verdade e Consenso: constituição, hermenêutica e teorias discursivas. Rio de Janeiro: Lumen Juris, 2006, p. 217.

27. RAMIRES, Maurício. Crítica À Aplicação de Precedentes No Direito Brasileiro. Porto Alegre: Livraria do Advogado, 2010, p. 105.

28. STRECK, Lenio Luiz. O Que É Isto Decido Conforme Minha Consciência?. Porto Alegre: Livraria do Advogado, 2010, p. 98.

29. STRECK, Lenio Luiz. Hermenêutica, Constituição, Autonomia do Direito e o Direito Fundamental A Obter Respostas Adequadas (Corretas). Revista da Faculdade de Direito do Sul de Minas. № 25, Jul-Dez, 2007, p. 140-143.

30. SAAVEDRA, Giovani Agostini. Jurisdição e Democracia: uma análise a partir das teorias de Jürgen Habermas, Robert Alexy, Ronald Dworkin e Niklas Luhmann. Porto Alegre: Livraria do Advogado, 2006, p. 84.

31. STRECK, Lenio Luiz. Hermenêutica, Constituição, Autonomia do Direito e o Direito Fundamental A Obter Respostas Adequadas (Corretas). Revista da Faculdade de Direito do Sul de Minas. № 25, Jul-Dez, 2007, p. 148-149.

32. SAAVEDRA, Giovani Agostini. Jurisdição e Democracia: uma análise a partir das teorias de Jürgen Habermas, Robert Alexy, Ronald Dworkin e Niklas Luhmann. Porto Alegre: Livraria do Advogado, 2006, p. 73.

33. SAAVEDRA, Giovani Agostini. Jurisdição e Democracia: uma análise a partir das teorias de Jürgen Habermas, Robert Alexy, Ronald Dworkin e Niklas Luhmann. Porto Alegre: Livraria do Advogado, 2006, p. 77-78.

34. HOMMERDING, Adalberto Narciso. Fundamentos Para Uma Compreensão Hermenêutica do Processo Civil. Porto Alegre: Livraria do Advogado, 2007, p. 35.

35. STRECK, Lenio Luis. Verdade e Consenso: constituição, hermenêutica e teorias discursivas. Rio de Janeiro: Lumen Juris, 2006, p. 257.

36. STRECK, Lenio Luiz. Verdade e Consenso: constituição, hermenêutica e teorias discursivas. Rio de Janeiro: Lumen Juris, 2006, p. 6.

37. STRECK, Lenio Luiz. Hermenêutica Jurídica $\mathbf{e}(\mathbf{m})$ Crise: uma exploração hermenêutica da construção do Direito. Porto Alegre: Livraria do Advogado, 2005. Passim.

38. ISAIA, Cristiano Becker. Processso Civil, Atuação Judicial e Hermenêutica Filosófica: a metáfora do juiz instrutor e a busca por respostas corretas em direito. Faticidade e Oralidade. Curitiba: Juruá, 2010, p. 91.

39. RAMIRES, Maurício. Crítica À Aplicação de Precedentes No Direito Brasileiro. Porto Alegre: Livraria do Advogado, 2010, p. 119.

40. OLIVEIRA, Rafael Tomaz. Decisão Judicial e o Conceito de Princípio: a hermenêutica e a (in)determinação do Direito. Porto Alegre: Livraria do Advogado, 2008, p. 131-132.

41. STRECK, Lenio Luiz. Hermenêutica Jurídica $\mathbf{e}(\mathbf{m})$ Crise: uma exploração hermenêutica da construção do Direito. Porto Alegre: Livraria do Advogado, 2005, p. 194-196.

42. HOMMERDING, Adalberto Narciso. Fundamentos Para Uma Compreensão Hermenêutica do Processo Civil. Porto Alegre: Livraria do Advogado, 2007, p. 68.

43. RAMIRES, Maurício. Crítica À Aplicação de Precedentes No Direito Brasileiro. Porto Alegre: Livraria do Advogado, 2010, p. 121.

44. STRECK, Lenio Luiz. Hermenêutica, Constituição, Autonomia do Direito e o Direito Fundamental A Obter Respostas Adequadas (Corretas). Revista da Faculdade de Direito do Sul de Minas. № 25, Jul-Dez, 2007, p. 144.

45. STRECK, Lenio Luiz. Hermenêutica Jurídica $\mathbf{e}(\mathbf{m})$ Crise: uma exploração hermenêutica da construção do Direito. p. 207.

\section{REFERÊNCIAS}

CAPPELLETTI, Mauro. Juízes Legislaores? Porto Alegre: Sergio Antonio Fabris, 1999. 
CAPPELLETTI, Mauro. Juízes Irresponsáveis? Porto Alegre: Sergio Antonio Fabris, 1989.

DWORKIN, Ronald. Levando Os Direitos À Sério. São Paulo: Martins Fontes, 2007.

DWORKIN, Ronald. O Império do Direito. São Paulo: Martins Fontes, 2007.

HOMMERDING, Adalberto Narciso. Fundamentos Para Uma Compreensão Hermenêutica do Processo Civil. Porto Alegre: Livraria do Advogado, 2007.

ISAIA, Cristiano Becker. Processo Civil, Atuação Judicial e Hermenêutica Filosófica: a metáfora do juiz instrutor e a busca por respostas corretas em direito. Faticidade e Oralidade. Curitiba: Juruá, 2010.

OLIVEIRA, Rafael Tomaz de. Decisão Judicial e o Conceito de Princípio: A hermenêutica e a (in)determinação do Direito. Porto Alegre: Livraria do Advogado, 2008.

RAMIRES, Maurício. Crítica À Aplicação de Precedentes no Direito Brasileiro. Porto Alegre: Livraria do Advogado, 2010.

RODRÍGUEZ, Cezar. La Decisión Judicial: el debate Hart-Dworkin. Bogotá: Siglo Del Hombre, 1997.

SAAVEDRA, Giovani Agostini. Jurisdição e Democracia: uma análise a partir das teorias de Jürgen Habermas, Robert Alexy, Ronald Dworkin e Niklas Luhmann. Porto Alegre: Livraria da Advogado, 2006.

SILVA, Ovídio A. Baptista da. Processo e Ideologia: o paradigma racionalista. Rio de Janeiro: Forense, 2006.

STRECK, Lenio Luiz. Verdade e Consenso: constituição, hermenêutica e teorias discursivas. Rio de Janeiro: Lumen Juris, 2006.

STRECK, Lenio Luiz. Hermenêutica Jurídica $\mathbf{e}(\mathbf{m})$ Crise: uma exploração hermenêutica da construção do Direito. Porto Alegre: Livraria do Advogado, 2005.

STRECK, Lenio Luiz. Hermenêutica, Constituição, Autonomia do Direito e o Direito Fundamental A Obter Respostas Adequadas (Corretas). Revista da Faculdade de Direito do Sul de Minas. № 25, Jul-Dez, 2007.

Recebido para publicação: 05/10/2011

Aceito para publicação: 23/12/2011 